OPEN ACCESS

Edited by:

Alexander Onysko,

University of Klagenfurt, Austria

Reviewed by:

Henrik Gottlieb,

University of Copenhagen, Denmark

Biljana Mišić llić,

University of Niš, Serbia

*Correspondence:

Irena Kapo

irenapata@gmail.com

Specialty section:

This article was submitted to

Language Sciences,

a section of the journal

Frontiers in Communication

Received: 20 September 2021

Accepted: 19 January 2022

Published: 09 February 2022

Citation:

Kapo I (2022) The Rising of "Alblish" (Albanian + English)-Data Collection and Analysis of Anglicisms in the Albanian Language.

Front. Commun. 7:780152

doi: $10.3389 /$ fcomm.2022.780152

\section{The Rising of "Alblish" (Albanian + English)-Data Collection and Analysis of Anglicisms in the Albanian Language}

\author{
Irena Kapo* \\ Department of English Language, University of Tirana, Tirana, Albania
}

This paper investigates the impact of English on the Albanian language, a language contact phenomenon hitherto largely unexamined by Albanian and non-Albanian linguists alike. This contact mainly started as an indirect one at the beginning of the twentieth century, primarily via translations, the establishment of several educational institutions with the support of American and British associations and Albanian immigration into English-speaking countries. Several newspapers introduced a considerable number of Anglicisms into Albanian during the first half of the twentieth century, a good quantity of which "survived" even during the communist years of isolation. Those Anglicisms which made their way into the Albanian language until the 1990s and which have established themselves in the Albanian of today are mainly from the domains of culture and sports. The fall of the communist regime exposed the Albanian language to external linguistic and social factors, bringing about a flood of Anglicisms in different lexical fields other than culture and sport, such as business, information technology, politics, and medicine. The current database of Anglicisms in Albanian used for the purpose of this Brief Research Report was collected in the framework of the GLAD (Global Anglicism Database Network) project, http://gladnetwork.org. It includes 1,895 Anglicisms from newspapers and dictionaries, all integrated in a single file. The report first provides background information regarding the growing impact of English on the Albanian language during the three time periods under review (early twentieth century until 1960, 1960 to 1990, and 1990 to the present day). This is followed by an account of the data and the methods applied in the research. Subsequently, the findings and results are presented and discussed from a morphological, lexical, and syntactical perspective. The final outcomes are then used as a basis for the identification of Albanian language structures or patterns the English borrowings have managed to penetrate as well as of the level of adaptation English borrowings have in Albanian.

Keywords: Anglicisms, language contact, pseudo-Anglicisms, morpho-syntactic analysis, semantic fields, Anglicisms/English borrowings, language contact-English/Albanian 


\section{INTRODUCTION}

The objectives of this brief research report are to provide evidence of how English has had an impact on Albanian from the beginning of the twentieth century, as well as to give an overview of the taxonomy of Anglicisms in the Albanian language.

For this purpose, the report focuses on English loanwords in the Albanian language. The main references used to determine the inclusion vs. exclusion of particular English borrowings/Anglicisms are the Etymological Dictionary of the Albanian Language by Kolec Topalli (2017), the four Albanian language dictionaries published by the Albanian Academy of Science (Cipo et al., 1954; Academy of Science of Albania, 1980, 1984, 2006), Manfred Görlach's Dictionary of European Anglicisms (Görlach, 2001) and Gaetano Rando's Dizzionario degli Anglicismi nell' Italiano Postunitario (Rando, 1987).

The indirect contact Albanian has had with the English language as well as British and American culture as a whole dates back to the beginning of the twentieth century, with numerous newspapers, translations from English as well as bilingual dictionaries published both within and outside the Albanian territory (D.J. Kamburi in 1915, K.A. Çekrezi in 1923, Nelo Dizdari in 1934, etc.-cited in Lloshi, 2011, p. 70). Among several other factors that contributed to this indirect language contact are the immigration of many Albanians into Englishspeaking countries such as Canada, the United States, England, or Australia and the establishment of several associations or cultural/sports clubs.

The impact of English on the Albanian language was considerably reduced during the approximately 50 -year-period of communist isolation and intensified again only after the 1990s. The 1960s are taken as the first borderline as it was during this decade that the so-called "language purifying" reforms started to be established and implemented by the regime.

A few studies on Anglicisms in the Albanian language have been conducted in the twenty-first century so far, some of them as part of texts on the lexicology of the Albanian language, as newspaper articles on borrowings in the Albanian language (such as the writings of Shehu, 2002; Shkurtaj, 2004; Lloshi, 2005, 2011; Memisha, 2011) or as the subject of Ph.D. projects. The two most noteworthy and most wide-ranging of the Ph.D. theses conducted on the subject, in terms of the time periods covered as well as the corpus size under examination are that of Këçira (2005) and Kapo (2013). While the former extracted about 100 Anglicisms from a corpus of 4 years of the "Laboremus" newspaper (published in English and Albanian by the Albanian Vocational School, a technical high school established in Tirana by the American Red Cross in 1921), the latter extracted about 511 Anglicisms from 30 titles of different newspapers and magazines between 1990 and 2012. Both works conclude with observations regarding the phonetic, morphological and semantic aspects of English borrowings in the Albanian language.

Lloshi is one of the few Albanian linguists and perhaps the first who has underlined the fact that many of the recent borrowings used in the Albanian language have a much longer history in this language; he has also challenged statements of several other linguists that the Albanian language contains far fewer
Anglicisms than any other language or that the frequency of their use is limited (Lloshi, 2005, p. 32).

Albanian is one of the 16 European languages included in Manfred Görlach's Dictionary of European Anglicisms (DEA) which "is concentrated on the modern lexis imported after World War II, with a cut-off date of 1995” (DEA: xvi). Görlach underlines the absence of studies on Anglicisms in the Albanian language: "...Albanian had no literature worth mentioning" (Görlach, 2002, p. x). He only refers to two articles by linguists of the University of Pristina in Kosovo, I. Mehmeti and V. Nuhiu included in Rudolf Filipovićs The English Element in European Languages (Filipović, 1982) as a basis for the Anglicisms used in the Albanian variety spoken in Kosovo. However, no studies or research projects on the impact of English on the Albanian language in Albania were taken into account. Therefore, the quantity and quality of the Anglicisms representing the Albanian language in the DEA is extremely limited. Notwithstanding the fact that Albania was not deeply explored as an area in this publication, Anglicisms have had an important place in Albanian for a long time.

\section{METHOD AND CRITERIA USED FOR THE COLLECTION AND INCLUSION OF ANGLICISMS FOR THIS STUDY}

About 90 newspaper titles from the three periods under review were consulted (the specific issues, with months and dates are cited in the Reference section) as well as the four Albanian Language Dictionaries published by the Academy of Science of Albania. These have been the source of the 1,895 Anglicism lemmas collected for the purpose of this study.

All the articles published in the newspapers were searched for Anglicisms with the titles as the main indicator for determining whether to read fully or simply screen the respective article, depending mainly on the topic and the source from which the information was taken. The fact that for the last 10 years these newspapers have been available online in digital format was of immense help during the research process. For research of earlier newspapers, they were physically retrieved from the fund of the Albanian National Library, consulted for the day and upon completion of work returned to the library staff within the same day. The English words and phrases identified in the newspaper articles were recorded alphabetically in Word files, together with the sentences they occurred in, the exact date, source, and page. If a word or phrase appeared more than three times, it was qualified as an eligible entry in the Anglicism lemma database built in an Excel file. The same procedure was followed for the Anglicism lemmas found in the four Albanian language dictionaries. The data was first alphabetically collected in a Word file and the entries were then incorporated in an Excel file with the purpose of collecting them for the GLAD Anglicism database [http:// gladnetwork.org].

The Excel file of the GLAD database provides columns for the types of Anglicisms, the first date of attestation and the frequency of occurrence (carrying the ${ }^{*}, * *$, or ${ }^{* * *}$ symbols to mark their 
frequency). This organization of Anglicism lemmas facilitated the counting and the interpretation of the collected data.

The first criterion considered for the inclusion of an Anglicism found in our corpus is directly related to Onysko's definition of an Anglicism as: "any word recognized in its form (spelling, pronunciation, morphology) as coming from English” (Onysko, 2007, p. 90).

Secondly, the graphic criterion was decisive for the inclusion of the Anglicisms in the database. This criterion counts for those loans that have retained their English spelling and pronunciation in all or some of their morphemes/phonemes.

Henrik Gottlieb (2020, p. 41) describes the phenomenon of "relay borrowings" which is a scenario of language contact that is close to what happens to Anglicisms in Albanian:

"Language A exports an expression $a$ to language $\mathrm{B}$, thus coining expression $a b$. This is then borrowed in language $\mathrm{C}$, resulting in expression $a b c . "$

After the World Wars "numerous translations and adaptations from the Romance languages like French, Italian as well as from German enriched the Greek-Latin portion of the modern Albanian language with a considerable number of neologisms" (Çabej, 1982, p. 122). Many schools were opened by Italian clergymen especially in the North of Albania; technology, commerce, finance and crafts were some other areas, apart from education, where Italian words entered the Albanian language in great numbers (Thomai, 1999, p. 226). This is also confirmed by Görlach (2002) who writes that "the dominance of Italian between 1916 and 1943 leads us to expect that English words would have been handed on through Italian" (p. 295). Këçira (2005), too, dedicates special attention to the English borrowings mediated in Albanian via the Italian language. Moreover, she introduces a list of Anglicisms mediated via the Italian language providing "a thematic ordering" in different semantic fields.

Thus, together with many Italianisms and French borrowings, many Anglicisms have been "transported" into Albanian via these two languages. Our corpus of Anglicisms shares $26 \%$ of the Anglicisms in the Italian language identified in Rando's Dizzionario degli Anglicismi nell'Italiano Postunitario (Rando, 1987).

For the purposes of this brief research report, the borrowings that have taken on distinctive features of the "transporting" languages (in our case, Italian or French) in their graphic form or in their pronunciation, have been excluded from our corpus of Anglicisms, for instance: [inovasion] for "innovation," or [golavarad3] for "goal average." Thus, the methodological concern related to the actual etymology of the loans collected is solved by retaining in the corpus those loanwords free from traces of French or Italian that have preserved English traces or indicators either in their graphic form or pronunciation, or extending to their semantic dimension.

At the same time, the corpus contains Greek- or Latin-based Anglicisms that can be listed as "internationalisms," as they have entered the Albanian language recently and mainly from English or American sources (such as the example of the loan "karizmë" (charisma), typical of the modern political discourse in Albania).
Another criterion used is the inclusion of semantic loans and loan translations in the database. This contributes to the final objective of this brief research report, i.e., identifying the degree of adaptation of English loans in the Albanian language.

\section{RESULTS}

This section presents some of the findings from the analysis conducted on the corpora of newspapers and dictionaries. First, the number and the percentage of the Anglicisms in the Dictionaries of the Albanian language will be shown. This includes the distribution of Anglicisms in the three time periods considered. A second subsection provides an analysis of the types of English borrowings in the Albanian language.

\section{Diachronic Considerations and Frequency of Anglicisms in Albanian}

In total, $31.18 \%$ of the Anglicisms of the database are collected from the Albanian language dictionaries. The number of Anglicisms in each of the dictionaries is given in Table $\mathbf{1}$.

Table 1 shows a rather constant volume of Anglicisms in Albanian from the 1950s to the 2000s. While the absolute numbers of Anglicism entries have been steadily increasing, the relative frequency measured on the total number of entries is actually the lowest in the most recent dictionary. To add to that, an increase of 47 Anglicisms from 1984 to 2006 is a rather small one.

The 1,895 Anglicism lemmas of the corpus include so-called "short-life Anglicisms," i.e. about 141 Anglicisms that, on average, have "lived and died" between 1910 and 1955 as well as so-called "revived Anglicisms," i.e., about 77 Anglicisms that entered the Albanian language during the first half of the twentieth century, "slept" during the isolation period, to be re-activated only after the 1990s.

The considerable number of Anglicisms, and all the constructions found, give an indication of how and how much the English language has permeated the Albanian journalistic discourse and entered the dictionaries. The following graph (Figure 1) illustrates the increasing trend of the use of Anglicisms in periods of 10 years, with the lowest numbers during the World Wars and during the isolation period.

If the time under investigation is divided into three periods, the graph in Figure 2 emerges, with the two highest peaks in the 1920s, with 230 Anglicisms, and the second peak in the 2000s, with 258 Anglicisms. These numbers support the fluctuations in the Anglicisms intake of Albanian, before and after the isolation period.

\section{Analysis of Types of English Borrowings in Albanian}

The total number of Anglicisms extracted from the corpora is 1,895. Figure 3 shows the distribution of the types of English borrowings in Albanian with 730 adapted borrowings (xhins for the English jeans, diskurs for the English discourse, etc.), 571 unadapted borrowings (free lance, full time, etc.), 132 loan translations (jashtëshkollor for the English extracurricular, 
TABLE 1 | Anglicisms in the dictionaries of the Albanian language.

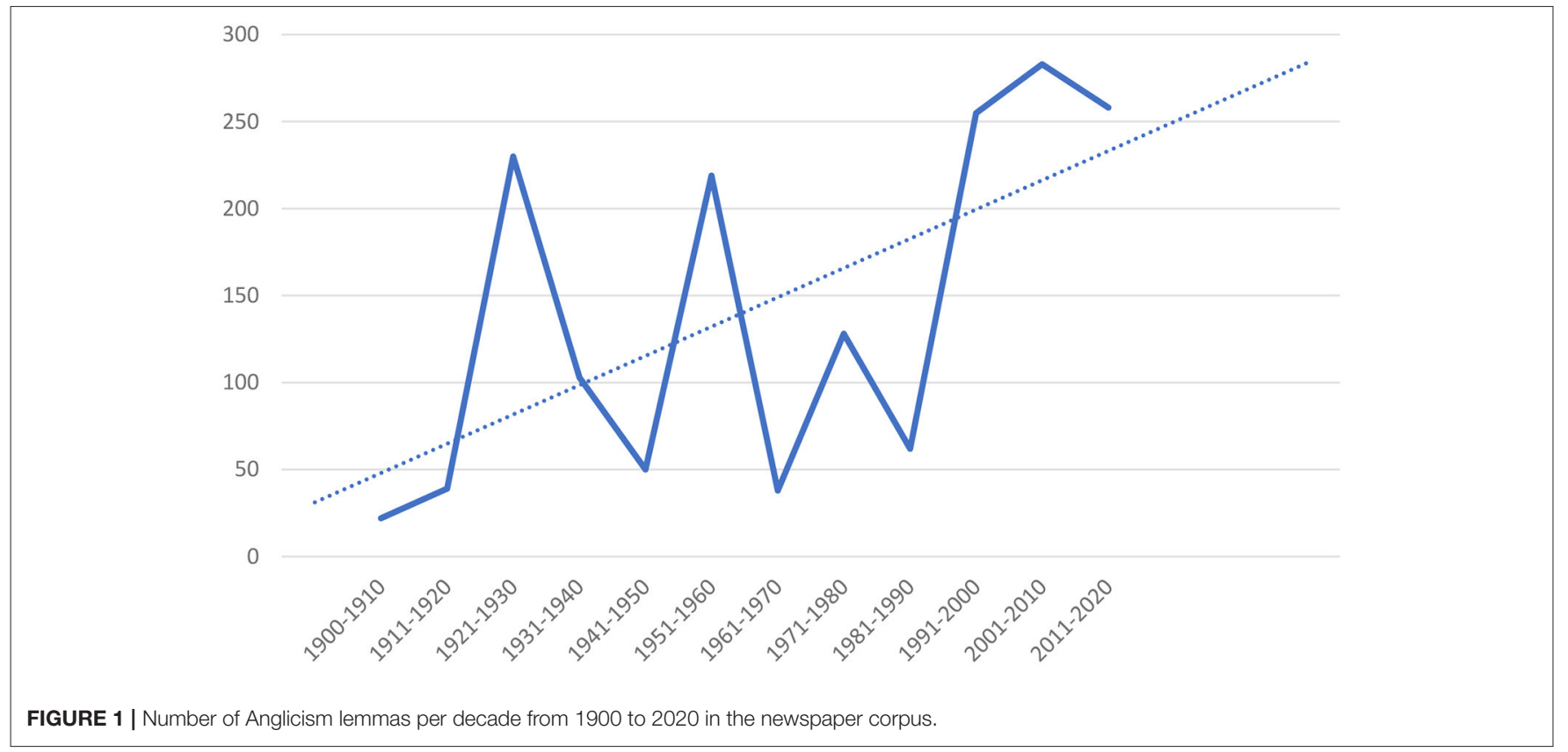

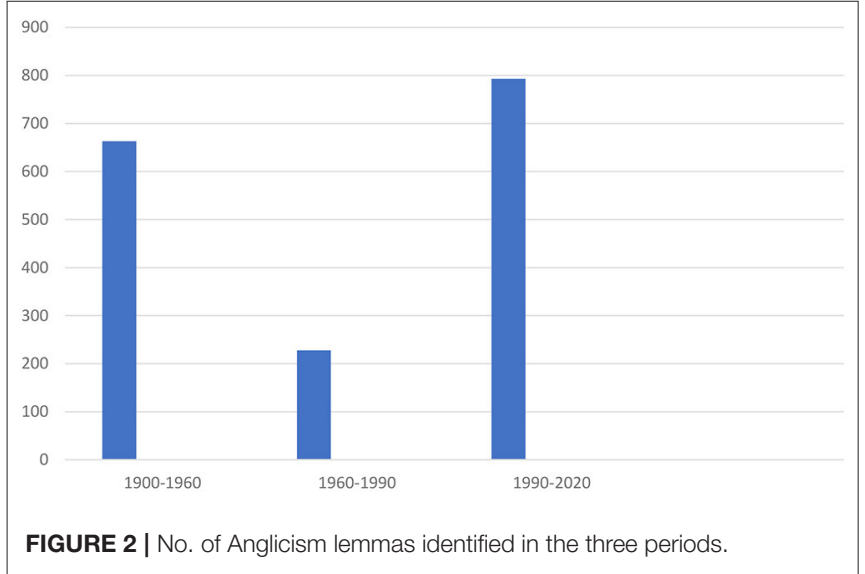

fundjavë for weekened, etc.), 480 hybrids (printim: print + the Albanian noun formation suffix -im for the English noun print, gugëlloj: google + the Albanian verb formation suffix -oj for the English to google, etc.), 105 pseudo-Anglicisms (kondicioner for the English air conditioner, kritik for the English critical, etc.), and 14 semantic loans (profil, qasje, llogari, etc. acquiring new meanings in Albanian under the impact of the English language).

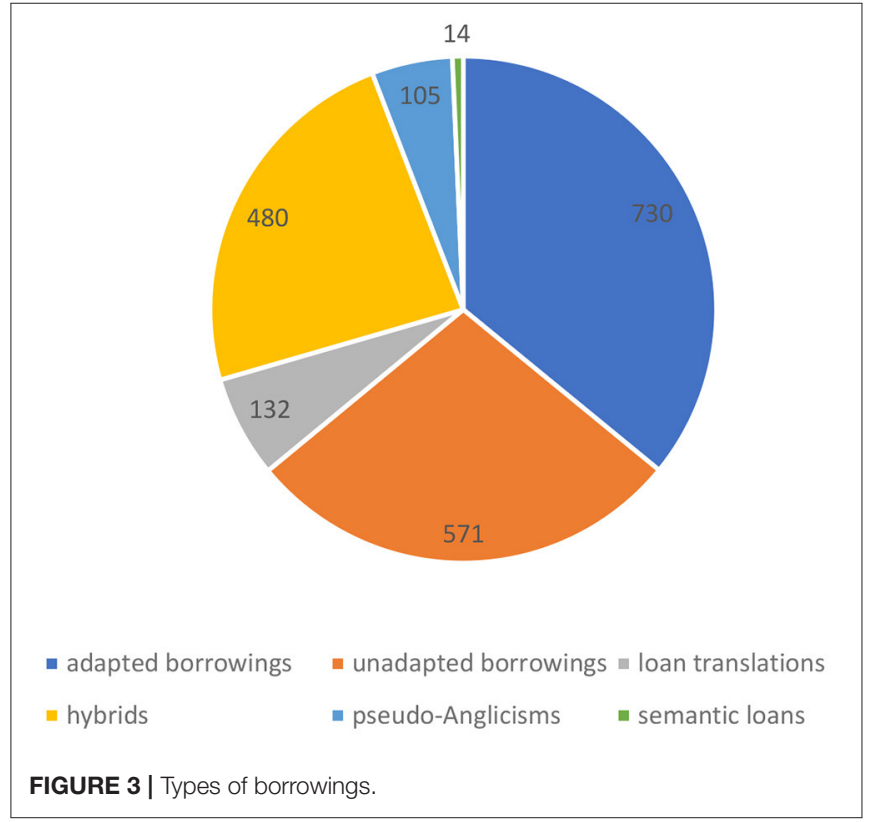

Figure 3 includes 141 "short-life Anglicisms" and 77 "revived Anglicisms." 
The first group of "short-life Anglicisms" (7.4\% of the corpus) includes entries such as:

1) the adapted borrowings aktres (actress) 1933-1943, bek (back-the player in the football game) 1930-1953, egoistik (egoistic) 1922-1942, etc.;

2) the unadapted borrowings blond (blond) 1928-1954, round (round-in wrestling) 1933-1949, etc.;

3) the hybrids eksploatim ("exploit+atim" for the English exploration) 1922-1952, etc., eksprorijoj ("expropriate+oj" for the English to expropriate) 1923-1933, etc.;

4) the pseudo-Anglicisms centerfor (the clipped centerfor for the English center forward) 1933-1964, half (for the English half-back in football) 1930-1953, etc.;

5) the loan translations centërsulmues (center - for the Albanian qendër +sulmues-forward from the English centreforward) 1938-1964, topekambë (top+e+kambë: ball + and + foot for the English football) 1943-1954, etc.

Examples in the second group, the "revived Anglicisms" (4.06\%), recognize:

1) adapted Anglicisms such as the adjective ekstrem (for the English extreme) 1933-1945 and 1980-on, bilion (for the English billion) 1922-1938 and 1980-on, etc.;

2) the unadapted Anglicisms fair play (for the English fair play) 1922-1922 and 1996-on, surplus (for the English surplus) 1938-1938 and 2011 and on, etc.;

3 ) the pseudo-Anglicisms flirt (for the English noun flirtation) 1939-1939 and 1996-on, ent (for the English entity) 19261954 and 1990-on, etc.;

4) the hybrids elaborim (elaborate+im for the English elaboration) 1930-1933 and 1990-on, atakoj (attack+oj for the English verb to attack) 1927-1954 and 2013-on, etc.; and

5) the loan translations liria e shtypit (for the English freedom of the press) 1930-1955 and 1980-to date, etc.

As words and phrases of the Recipient Language coined with English constituents or inspired by English formations with no immediate counterpart in the source language, the pseudoAnglicisms of the Albanian language constitute 5.5\% of all the entries in the corpus. The following classification is conducted with reference to Gottlieb's typology and formations of pseudoAnglicisms, based on Carstensen's German-based typology (Academy of Science of Albania, 1980), Furiassi (2010) regarding Italian and Fjeld's article on Norwegian lexicology (Fjeld, 2011):

1) "clippings (constituting the largest group of pseudo-Anglicisms in Italian) (Furiassi, 2010)

2) recombination of English morphemes

3) neosemantization of English lexemes (including semantic fossils and semantic neologisms" (Gottlieb, 2020, p. 208).

More than $70 \%$ of the pseudo-Anglicisms of our corpus can be categorized as belonging to the categories of "morphological change" or clipping. This category is common in many other European languages, as shown in Manfred Görlach's DEA (Görlach, 2001), affirmed also by Carstensen with the term
"World-Wide Pseudo-English" (Carstensen, 1986, p. 831). Some examples still in use in current Albanian are: "exchange" (from exchange office), "glos" (from lip gloss), "happy end" (from happy ending), "ski" (from skiing), "nul" (from null and void), etc.

In the group of recombinations with English and Albanian constituents but with no counterpart in the source language, "bllokmen" is an example for a coinage typical for the Albanian language. "Block+men" refers to a "senior member of the government during the communist regime living in the area of bllok" - "the headquarters of the communist Albanian government in an isolated area near the center of Tirana." Other examples of recombination are "fotoreporter," "drogmen," "autostop," most probably via the impact of other languages.

The group of English pseudo-loans that has undergone a change in word class or that has developed a new sense in the Albanian language-the category of neosemantizationconstitute $9.2 \%$ of the pseudo-Anglicisms collected. An example is "business lunch," used in Albanian as referring to "a special offer/discount restaurants make to people working in different institutions or organizations during their lunch break, usually fixed menus at a low price," and for the "change-of-word-class category:" "big up" used as a noun in Albanian.

There are also a few examples of spelling adaptations of English loan words in Albanian like: "ence" [entse] (for handsthe English hands-the offense of touching the ball with your hands in football, 1930-1950) and "xhem" [dzem] (for jump ball in basketball, 1953-1989), two loanwords coined in Albanian from the "perceived pronunciation" of (mainly) non-English speaking Albanians regarding these two English sports terms. Nevertheless, the former is no longer in use while the latter is still used in colloquial speech.

From the 1,895 entries of the corpus, 1,305 are nouns, 252 adjectives, 173 verbs, 16 adverbs, and 4 are interjections. Most of the hybrids of the corpus, coined with English stems and Albanian word formation suffixes are fully integrated in the morphological system of the Albanian language, i.e., hybrid verbs are conjugated, and hybrid nouns take case, number, and gender inflections similar to the native words.

The number of compounds amounts to about 73 entries with different compound patterns, such as:

"noun + noun" compounds [databazë (for "database"), fundjavë (for "weekend”), kameraman (for “cameraman”), etc.]

"adjective + noun" compounds [superyll (for "superstar"), toplistë (for “toplist”), etc.].

The number of free phrases recognized in the database mainly as loan translations amounts to about 68 , including noun and verb phrases such as "tavolinë e rrumbullakët" for round-table, "shoqëria civile" for civil society, etc.

In terms of word formation and the productivity of the English loans in Albanian, there appear to be about 253 word families or $16.6 \%$ of the corpus, from two to five constituents, coined with English constituents and Albanian suffixes: e.g., "lob-lobojlobim-lobues" for the English "lobby (n.)-lobby (v.)-lobbyist": the English stem lob plus the Albanian verb formation suffix $o j$, the Albanian noun formation suffix -im, and the Albanian adjective formation suffix -ues, etc. 


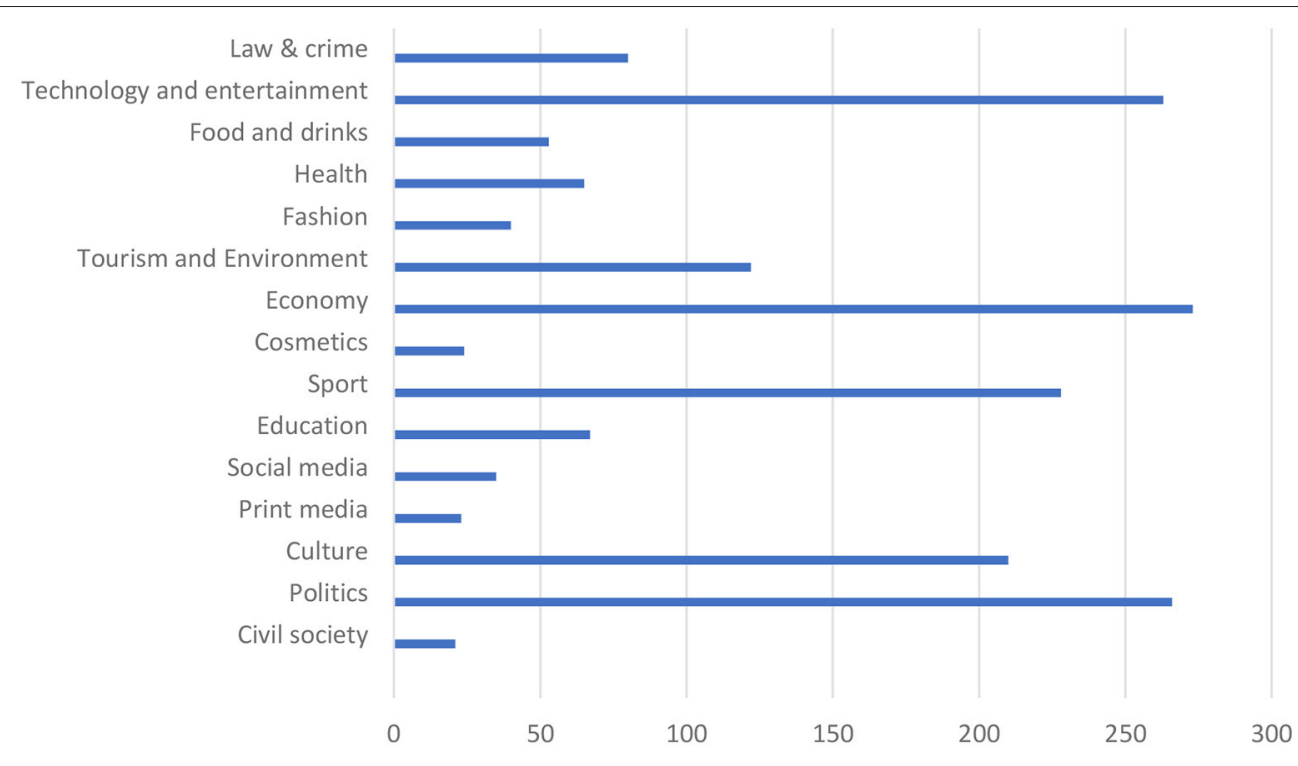

FIGURE 4 | Semantic fields.

The English adjective top appears not only in unadapted compounds like top-ten or top secret, but it has become very productive with many other nouns in Albanian, such as "topformacion" and "top-ekip" (for top formation and top-teamreferring to football teams in particular), top-dokument (for top-document), top-blerje (for the best buy), etc.

The corpus includes 35 acronyms, most of which are unadapted in Albanian, both in their spelling and pronunciation (DJ pronounced ['di: dze1], CD [si: di:] DVD [di: vi: di:], GDP [dzi: di'pi:]), etc.

The semantic fields to which the Anglicisms found in the corpus can be attributed are shown in Figure 4.

\section{DISCUSSION OF RESULTS}

This brief research report, built on a corpus of 1,895 Anglicisms in the Albanian language, sheds light on the non-steady intake of English loanwords in the Albanian language. The results show the influence of the communist regime on the use of Anglicisms in the written Albanian newspaper language with peaks before and after that. The results of the dictionary data, on the other hand, show a rather stable presence of Anglicisms.

Diachronic considerations on Anglicisms in Albanian are illustrated in Figures 1, 2. The first period taken into consideration, 1900-1960, accounts for a number of Anglicisms that, in a way, formed the first layer of English borrowings in the Albanian press language. In total, 7.4\% of the Anglicisms of the corpus "lived and died" during this first period, while $4.06 \%$ Anglicisms of the corpus "were born" during the first period, came out of use during the second period, and were "revived" in the third period.
The isolation years and the lack of external linguistic and extra-linguistic factors justify the lowest number of Anglicisms in the second period and the growing trend in the third period under consideration. After the second peak, that of the 2000s (with 258 Anglicisms) - as illustrated in Figure 1-we can speak of a "layer of English loans" adding to the Albanian lexicon, reinforcing the first layer established in the first period.

The data collected provide sufficient evidence for an analysis of the morphological and semantic features of English borrowings in the Albanian language.

As Haspelmath (2008, p. 7) states "Nouns are borrowed more easily than other parts of speech." In our corpus, the majority of Anglicism lemmas are nouns, with about $70 \%$ of all loan entries. The corpus of the Anglicisms collected from the newspapers shows that they can occur in various sentential positions and contexts. The majority of the nominal and adjectival English loans take inflectional and derivational endings of their respective gender, number, and case, according to the Albanian language rules.

An indicator of "good integration" is the occurrence of compounds with native elements ( $25.3 \%$ of the corpus are hybrid formations). Referring to the numerous phrases, sentences, and contexts in which they appear, it can be affirmed that the majority of the English borrowings seems to have found their way into the Albanian language.

The percentage of unadapted borrowings is $30.7 \%$. However, based on the number of examples retrieved for each of the Anglicisms of the corpus and on the rated frequency defined in the GLAD database, it can be estimated (even though rather subjectively) that from the unadapted Anglicisms of the corpus, $64 \%$ are very frequently and frequently used. Furthermore, about $35 \%$ of the adapted borrowings in the corpus, including loan translations, hybrids, pseudo-Anglicisms, and semantic 
loans support the claim that there is a considerable degree of occurrence of Anglicisms in the Albanian newspapers consulted for the purpose of this research.

Onysko (2007, p. 52) regards the definition of pseudoAnglicisms as "bordering on morphological and semantic changes of borrowings in the Recipient Language." As such, most of our pseudo-Anglicisms (about 70\%) were coined via morphological changes and about $10 \%$ via semantic changes. The various semantic fields pseudo-Anglicisms belong to (sport, culture, technology, etc.), the English-influenced "new entries" in the Albanian lexicon as a result of "neosemantization" and "recombination" processes and their quantity of about $5 \%$ of the whole corpus is in line with Gottlieb's observation on pseudoAnglicisms, namely that "they are rare but are useful" (Gottlieb, 2020, p. 204).

The criterion to include "loan translations" and "semantic loans" in the corpus served to test the integration of these two types of borrowings in the morphosyntactic structure of the Albanian language. From the cases investigated, about $4.2 \%$ of the corpus of our Anglicisms mark the initiation or the first stage of the loans' integration into the syntactic structures of the Albanian language. When a new meaning is introduced to the already existing lexemes in Albanian (the case of semantic loans) and when the English compounds or phrases are translated in Albanian (the case of loan translations), these two categories introduce neologisms and "new entries" to the Albanian lexicon: burime njerëzore (from "human resources"), elefanti në dhomë (from "the elephant in the room"), etc. Other neologisms introducing new notions, inventions, technological, cultural, culinary, etc. terms in Albanian are: "kompjuter" (for computer), "logo," "set," "sanduiç" (for sandwich), "link," "haker" (for hacker), "pas" (for pass the ball in football), etc.

Referring to the data provided in Figure 4, the semantic fields that top the list of the Anglicisms of our corpus are those from the areas of business, politics, information technology, sport, and culture.

\section{REFERENCES}

Academy of Science of Albania (1980). Dictionary of Modern Albanian Language. Tirana.

Academy of Science of Albania (1984). Dictionary of Modern Albanian Language. Tirana.

Academy of Science of Albania (2006). Dictionary of Albanian Language. Tirana.

Çabej, E. (1982). Studime Etimologjike në Fushë të Shqipes, (Etymologycal Studies on the Albanian language), Vols. I, II, III, IV, V, VI, VII. Tirana: Akademia e Shkencave e RPS të Shqipërisë (Academy of Science of the Socialist Republic of Albania).

Carstensen, B. (1986). "Euro English," in Linguistics across Historical and Geographical Boundaries: In Honor of Jacek Fisiak. Vol. 2: Descriptive, Contrastive and Applied Linguistics, eds D. Kastovsky and A. Szwedek (Berlin: Mouton de Gruyter), 827-835.

Cipo, K., Çabej, E., Domi, M., Krajni, A., and Myderrizi, O. (1954). Dictionary of Albanian Language. Tirana.

Filipović, R. (1982). The English Element in European Languages. Institute of Linguistics, Faculty of Philosophy, University of Zagreb.

\section{CONCLUSION}

The data and findings underscore the long-standing history of English and Albanian language contact and the oscillations this contact has been subject to since 1900 to date. The English loans collected for the purpose of this study were extracted from sources likely to reflect common language usage. Being only a manual micro-level analysis and with a few digitalized texts available, this research is limited regarding its provision of accurate numbers of English borrowings in terms of article hits and the share these Anglicisms have in relation to the total word number of the respective piece of writing. Thus, this study is by no means complete and conclusive.

In sum, the present study provides sufficient evidence and analysis for the starting point of an indirect English-Albanian language contact; it also provides some indicators regarding the linguistic "itinerary" English loan words have been taking into the Albanian language; the distribution of Anglicisms in various semantic fields, the "co-existence" with Albanian inflections, prefixes and suffixes or even as part of compounds and free phrases in Albanian point to the regular processes of how English loans become integrated in a range of RLs (without leading to deeper structural/grammatical changes of the RLs). Extensive code-switching during the last 10 years, in particular by the young generation but also by the media (subject to future research), further supports the rising of "Alblish" in the territory of Albania.

\section{DATA AVAILABILITY STATEMENT}

The raw data supporting the conclusions of this article will be made available by the authors, without undue reservation.

\section{AUTHOR CONTRIBUTIONS}

The author confirms being the sole contributor of this work and has approved it for publication.

Fjeld, R. V. (2011). "Leksikalsk neografi i Norge," in Nye ord. Sprognounets Konferenceserie 1, eds M. H. Andersen and J. N. Jensen (Copenhagen: Dansk Sprognævn), 19-39.

Furiassi, C. (2010). False Anglicisms in Italian. Milano: Polimetrica.

Görlach, M. (2001). A Dictionary of European Anglicisms, A Usage Dictionary of Anglicisms in Sixteen European Languages, Oxford: Oxford University Press.

Görlach, M. (2002). An Annotated Bibliography of European Anglicisms. Oxford: Oxford University Press.

Gottlieb, H. (2020). Echoes of English. Anglicisms in Minor Speech Communities - with special Focus on Danish and Afrikaans. Berlin: Peter Lang AG.

Haspelmath, M. (2008). "Loanword typology: steps toward a systematic crosslinguistic study of lexical borrowability," in Aspects of Language Contact: New Theoretical, Methodological and Empirical Findings with Special Focus on Romancisation Processes, eds T. Stolz, D. Bakker, and R. S. Palomo (Berlin; New York, NY: De Gruyter Mouton), 43-62.

Kapo, I. (2013). 'Monograph': Influence of English Language in the PostCommunist Written Press in Albania, Dritan.

Këçira, R. (2005). Anglicisms in Albanian: A Direct and Mediated Language Contact Phenomenon. Graz: Institut für Anglistik. 
Lloshi, X. (2005). "Shqipja përballë rrjedhave të globalizmit (facing the globalization: the case of the Albanian language)," in Studia Albanica (Tirana: Academy of Sciences of Albania), 47-56.

Lloshi, X. (2011). Raste Ndërhyrjesh të Huazimeve Nga Anglishtja (Cases of English Loans in Albanian language), Studime Filologjike - Phylological Studies. no. 1-2.

Memisha, V. (2011). Studime për Fjalën Shqipe (Studies on Albanian Language). Qendra e Studimeve Albanologjike, Instituti i Gjuhësisë dhe i Letërsisë, (Center for Albanological Studies, Institute for Language and Literature), Tirana: Botart Publishing House.

Onysko, A. (2007). Anglicisms in German. Borrowing, Lexical Productivity, and Written Codeswitching. Berlin; New York, NY: Walter de Gruyter.

Rando, G. (1987). 'Dizzionario degli Anglicismi nell'Italiano Postunitario. Firenze.

Shehu, H. (2002). Rreth Anglicizmave në Mjetet e Sotme të Informimit Masiv, (On Anglicisms in the Modern Mass Media), Studime Filologjike, 3-4. Akademia e Shkencave e Shqipërisë, Instituti i Gjuhësisë dhe i Letërsisë (Academy of Science of Albania, Institute for Language and Literature).

Shkurtaj, G. (2004). Drejtshkrimi dhe Drejtshqiptimi në mediat e sotme të shkruara dhe të folura, (The correct writing and pronunciation in the modern written and spoken media). Gjuha Jonë.
Thomai, J. (1999). Lexicology of the Albanian Language. University of Tirana Publishing House.

Topalli, K. (2017). Etymological Dictionary of the Albanian Language. Academy of Albanological Studies.

Conflict of Interest: The author declares that the research was conducted in the absence of any commercial or financial relationships that could be construed as a potential conflict of interest.

Publisher's Note: All claims expressed in this article are solely those of the authors and do not necessarily represent those of their affiliated organizations, or those of the publisher, the editors and the reviewers. Any product that may be evaluated in this article, or claim that may be made by its manufacturer, is not guaranteed or endorsed by the publisher.

Copyright (c) 2022 Kapo. This is an open-access article distributed under the terms of the Creative Commons Attribution License (CC BY). The use, distribution or reproduction in other forums is permitted, provided the original author(s) and the copyright owner(s) are credited and that the original publication in this journal is cited, in accordance with accepted academic practice. No use, distribution or reproduction is permitted which does not comply with these terms. 


\section{NEWSPAPERS AND \\ MAGAZINES CONSULTED}

\section{0-1960}

Elcija i Zemres t'Jezu Krisctit, Kalendari, Korça, Drita, Hylli Dritës, Atdheu, Tomorri, Atdheu, Besa Shqyptare, Përparimi, Posta e Shqypnies, Kopështi letrar, Agimi, Adriatiku, Koha, Bagëti e Bujqësi, Fletore Zyrtare, Shqiptari Amerikës, Afrimi, Dajti, Republika, Laboremus, Demokratia, Revista Pedagogjike, Telegraf, Kombi Shqiptar, Gazeta Shqiptare, Gazeta e Re, Gazeta e Korçës, Arbëria, Besa, Gazeta e Tiranës, Vatra, Vullneti i Popullit, Cirka, Shtypi, Kombi, Bota e re, Balli
Rinis, Bashkimi, Fletorja e Kryqit të Kuq Shqiptar, Sporti, Hosteni, Arsimi, Puna, Sporti popullor, Zëri i Rinisë, Zëri popullit, Ylli.

1960-1990

Ylli, Drita, Hosteni, Mësuesi, Sporti Popullor, Skena dhe Ekrani, Bashkimi

1990-2020

Sporti, Koha Jonë, Klan, Albania, Rilindja Demokratike, Shekulli, Gazeta Shqiptare, Republika, Jeta, Panorama, Korrieri, Spektër, Shqip, VIP, Studenti, Tema, Dita, Standard, Sport Ekspres, "55”, Metropol, Monitor, Psikologji, Telegraf, GameOver, Mapo, Sot. 